\title{
PERBANDINGAN TEORI DISRUPSI PADA MARKETING DI ERA INDUSTRI 4.0 MENURUT HERMAWAN KARTAJAYA DAN RHENALD KASALI
}

\author{
Akhmad Sefudin ${ }^{1}$, Muhammad Darwin ${ }^{2}$ \\ ${ }^{1}$ Universitas Indraprasta PGRI Jakarta \\ ${ }^{2}$ Universitas Nasional Jakarta \\ Email: sefudinakhmad@gmail.com
}

\begin{abstract}
Abstrak
Tujuan dari penelitian ini adalah untuk mengetahui perbandingan teori disrupsi pada marketing di era Revolusi Industri 4.0 oleh Hermawan Kartajaya dan Rhenald Kasali. Adapun pembatasan penelitian, terbatas pada literatur-litereatur yang berkaitan dengan disrupsi pada marketing. Penelitian ini menggunakan metode penelitian kualitatif. Hasilnya adalah teori disrupsi pada marketing dari kedua pakar secara bersama menjelaskan bahwa, terjadinya gangguan dan perkembangan teknologi yang sedang dihadapi sekarang mengharuskan marketer harus melakukan pendekatan pemasaran yang baru sejalan dengan Revolusi Industri 4.0. Adapun perbedaan konsep teori hanya terletak pada istilah dan sebutan konsep saja yang pada Hermawan Kartajaya menyebutnya dengan konsep Marketing 4.0 sedangkan Rhenald Kasali menyebutnya dengan konsep \#MO. Pada dasarnya kedua teori sama-sama menjelaskan bagaimana marketer mampu menjual produk ke konsumen yang semakin inklusif, smart, sosial dan horizontal.
\end{abstract}

Kata Kunci: Marketing 4.0, Mobilisasi, Orkestrasi.

\begin{abstract}
The purpose of this study is to compare the theory of disruption in marketing in the era of the Industrial Revolution 4.0 by Hermawan Kartajaya and Rhenald Kasali. Research rights, are limited to the literature related to marketing disruption. This study used qualitative research methods. The result is a theory of disruption in marketing from the two experts who jointly explain that the disruption and development of technology that is now required marketers to take a new marketing approach in line with the Industrial Revolution 4.0. The definition of the theoretical concept only lies in the terms and designations of the concept which Hermawan Kartajaya calls the Marketing concept 4.0 while Rhenald Kasali refers to the \#MO concept. The second theory both explains how marketers are able to sell products to consumers who are more inclusive, smart, social and horizontal.
\end{abstract}

Keywords: Marketing 4.0, Mobilization, Orchestration.

\section{A. PENDAHULUAN}

Era saat ini adalah era perubahan yang sangat cepat terjadi, hal ini dirasakan oleh seluruh negara di dunia (Volatility). Tantangan Globalisasi menuntut semua negara harus mengikuti perkembangan tanpa batas. Revolusi Industri 3.0 yang sebelumnya mengandalkan semikonduktor dan otomatisasi industri yang masih mengarah kepada era digitalisasi. Sekarang telah sampai kepada Revolusi Industri 4.0 ciri utamanya terjadi 


\section{ARTIKEL}

disrupsi diberbagai lini yang semuanya telah masuk pada era digitalisasi secara penuh dan dinamis (Uncertainty). Industri 4.0 adalah interaksi antara Cyber Physical System (CPS) dengan Inter of Things and Service (IoT dan IoS) (Dalenogare et al., 2018). Terjadinya perang dagang antara negara Amerika Serikat (Amerika) dengan negara Cina (Asia). Ketegangan politik dan militer antara Amerika Serikat dan Iran (Timur Tengah). Berimbas kepada perekonomian global seperti naiknya harga minyak dunia dan mata uang dollar AS, kejadian tersebut berpengaruh secara signifikan terhadap pertumbuhan perekonomian setiap negera.

Kondisi ini diperparah dengan adanya Pandemi yang dialami. Coronavirus 2019 menjangkit manusia yang menyebar keseluruh dunia. Akibat dari perubahan-perubahan tersebut telah memberikan kompleksitas masalah yang dihadapi seluruh negara. Dunia sekarang sedang mengalami masa perubahan yang tidak menentu, kondisi lingkungan yang dinamis dan saling ketergantungan (Complexity). Banyak upaya dan solusi yang dicari untuk mengatasi segala aspek, baik kemunduran ekonomi, kesehatan, pendidikan, kemiskinan, pengangguran dan lain-lain. Kondisi yang luar biasa dan ambigu (Ambiguity) ini akan membuat negara harus berhati-hati mencari jalan keluar atas segala permasalahan yang ada. Jika upaya dan solusi yang dijalankan tidak tepat sasaran maka akan mudah suatu negara tersebut terjerumus dalam ambang resesi dan kehancuran.

Kondisi yang sedang dihadapi sekarang, telah sampai pada kondisi yang sudah dipopulerkan oleh US Army War Collage, lebih dikenal dengan akronim VUCA. Vuca menjelaskan lebih volatil, tidak pasti, kompleks dan ambigu keadaan dunia multilateral pada akhir perang dingin. Akronim ini diadopsi oleh para pemimpin strategis untuk menggambarkan keadaan lingkungan bisnis yang semakin tidak pasti, kompleks dan ambigu serta berubah dengan cepat (Potsangbam, 2018). Pertama sekali akronim ini digunakan pada tahun 1987 berdasarkan teori kepemimpinan Warren Bennis dan Burt Nanus untuk menggambarkan perubahan yang semakin cepat (Volatility), ketidakpastian masa depan (Uncertainty), faktor lingkungan yang dinamis dan saling ketergantungan (Complexity), keadaan yang tidak biasa dan diluar dari harapan dan satu keadaan saling berhubungan satu sama lain (Ambiguity).

Era Vuca yang sedang kita alami saat ini memberikan efek terhadap disrupsi yang sangat cepat terhadap berbagai aspek khususnya ekonomi. Ekonomi adalah salah satu aspek utama yang selalu menghadapi efek langsung atas segala aktivitas perubahan. Seperti yang dijelaskan sebelumnya pada perubahan globalisasi, revolusi industri, perang dagang dan kondisi pandemi. Setiap regulasi yang dimunculkan selalu mengutamakan kepentingan ekonomi daripada aspek lainnya. Hal ini dilakukan karena ekonomi adalah bagian terpenting yang harus dibenahi dan selanjutnya dengan harapan akan berpengaruh langsung terhadap aspek lain.

Aspek ekonomi khususnya pada bidang konsumsi sangat memberikan kontribusi yang penting dalam meningkatkan perekonomian. Upaya tersebut dilakukan agar kemiskinan, pengangguran dapat menurun. Dengan harapan tingkat konsumsi masyarakat semakin meningkat yang bertujuan untuk menyelamatkan GDP (Gross Profit Bruto). Maka dalam usaha tersebut tingkat konsumsi masyarakat harus diproritaskan agar jumlah uang beredar semakin memberikan kontribusi yang baik terhadap pertumbuhan ekonomi. Stimulus konsumsi masyarakat yang diberikan oleh pemerintah melalui beberapa paket kebijakan 
dalam bentuk bantuan tunai adalah suatu solusi efektif agar masyarakat mampu membelanjakan uangnya secara tunai dimasa krisis dan pandemi ini.

Peran pemasar dalam hal ini juga harus mampu memasarkan produknya menyesuaikan keadaan saat ini. Keadaan dimana konsumen dalam mengkonsumsi kebutuhannya harus menyesuaikan dengan kondisi ekonomi, pandemi dan perkembangan teknologi digital. Dalam kondisi pandemi misalnya, konsumen harus menjaga jarak dan tidak berhubungan langsung dengan produsen dalam bertransaksi. Sejalan dengan itu, era digital merupakan solusi dalam menjembatani kondisi tersebut dengan memberikan solusi yang efektif. Salah satunya dengan belanja secara online, hadirnya aplikasi zoom, hangout sebagai media belajar, meeting dan alat pertemuan online lainnya. Peran teknologi digital mempermudah masyarakat memperoleh segala kebutuhan yang diinginkan. Namun disisi lain kondisi ekonomi yang sedang dialami melemahkan tingkat keinginan masyarakat untuk berbelanja dan memperoleh kebutuhan. Inilah tantangan yang dimiliki oleh pemasar, tapi dengan adanya era digital saat ini akan bisa dimanfaatkan sebagai peluang.

Dari fenomena bisnis di atas, marketing juga telah mengalami disrupsi searah dengan perubahan-perubahan yang sedang terjadi. Implementasi teori-teori yang sebelumnya digunakan tentunya akan mengalami disrupsi. Karena ilmu pemasaran adalah ilmu yang dinamis. Ilmu yang dapat berkembang menyesuaikan dengan kondisi yang dihadapi. Teoriteori ilmiah yang digunakan sebelumnya harus didefenisikan ulang dan atau diberikan penambahan terbaharukan agar penerapannya sesuai dengan harapan yang dialami masa kini yang dinamis. Konsep pemasaran harus dapat berevolusi dan menyamai revolusi pada industri. Lanskap bisnis harus berubah dan bergerak ke ekonomi digital yang menciptakan ragam kemudahan yang tidak dapat dinikmati oleh generasi sebelumnya (Kartajaya, 2019).

Disrupsi pada pemasaran adalah akibat dari revolusi industri 4.0 seperti yang dikemukakan diatas. Menurut (Darwin, 2020) terjadinya disrupsi pada marketing adalah sejalan dengan terjadinya revolusi industri 4.0. Sesuai dengan buku yang ditulis oleh Kotler dan Hermawan K. (Kotler et al., 2019) dengan sebutan Marketing 4.0. Selanjutnya menurut Rhenald Kasali dengan sebutan Mobilisasi dan Orkestrasi (M\#O) (Kasali, 2019).

Dari konsep-konsep marketing yang telah disusun ulang dan diperkenalkan oleh kedua pakar tersebut, merupakan representative dari bagaimana memahami disrupsi marketing di era industri 4.0 saat ini. Hermawan Kartajaya adalah seorang pakar pemasaran yang bukan hanya dikenal di taraf Nasional tetapi juga Internasional. Bukunya telah diterjemahkan ke berbagai bahasa di dunia. Serta telah memiliki konektivitas keilmuan dengan berbagai pakar-pakar pemasaran dunia seperti Philip Kotler, keduanya sudah beberapa kali menulis buku bersama, yang terbaru kita kenal dengan buku Marketing 4.0 : Bergerak dari Taradisional ke Digital.

Rhenald Kasali adalah guru besar manajemen di Universitas Indonesia. Secara Nasional Rhenald Kasali sudah sangat dikenal sebagai pelopor rumah perubahan dan dalam bidang bisnis Rhenald Kasali telah beberapa kali menerbitkan buku, yang terbaru berjudul buku Series on Disruption : Mobilisasi dan Orkestrasi M\#O. Secara Internasional, Rhenald Kasali juga sudah sering mengisi seminar di berbagai Universitas terkemuka di dunia. Renald Kasali sangat berkontribusi terhadap penyebaran ide dan gagasan untuk perubahan dan kemajuan negara. Maka tak jarang Rhenald Kasali diundang sebagai pembicara di Media TV. Buku-bukunya telah banyak digunakan oleh praktisi bisnis dan akademisi sebagai referensi. 
ARTIKEL

Rhenald Kasali bukan hanya sebagai akademisi tetapi juga praktisi bisnis. Tentunya dengan pengalaman bisnis yang ditekuni, akademisi yang dijalani akan membuahkan teori yang matang dalam menjawab segala permasalah bisnis.

Maka untuk memahami lebih dalam teori terbaharukan tentang marketing. Penulis akan melakukan studi literatur yang telah ditulis oleh Hermawan Kartajaya dan Rhenald Kasali serta penelitian-penelitian lain yang telah mengembangkan teori keduanya. Batasan penelitian adalah pada literatur yang membahas tentang disrupsi marketing. Penulis akan membandingkan pemikiran keduanya dengan meneliti pandangan, teori dan penelitian yang sudah dilakukan.

\section{B. TINJAUAN PUSTAKA}

\section{Pengertian Marketing}

Menurut (Kartajaya, 2002) Marketing adalah merupakan kosep strategis bisnis yang bertujuan untuk meraih kepuasan bagi ketiga stakeholder utama yakni customer, people dan shareholder. Marketing adalah merupakan jiwa yang harus dimiliki oleh semua anggota organisasai. Maka dalam penerapannya, marketing harus dipandang dari sisi yang sangat luas. Yang selanjutnya Hermawan K mengembangkan konsep marketing tersebut menjadi tiga dimensi strategi yakni, Outlook, Architecture, Scorecard. Dapat digambarkan dalam gambar dibawah ini:

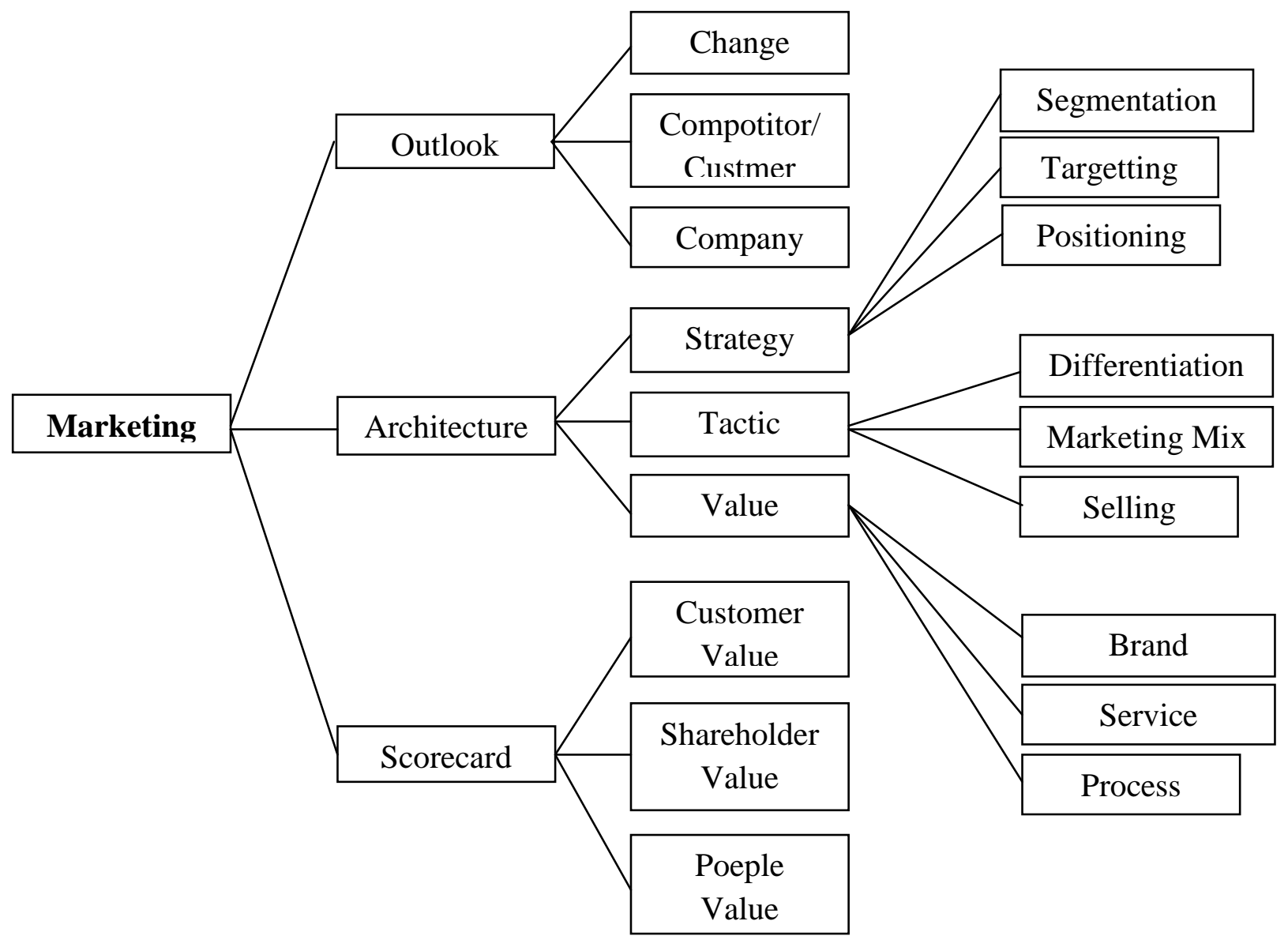

Gambar 1 Diagram Marketing

Sumber: Buku Hermawan Kartajaya on Marketing 
Sedangkan menurut (Kasali, 1998, p. 52) marketing adalah suatu konsep yang menyangkut sikap mental dan cara berfikir yang membimbing untuk melalukan suatu kegiatan yang bukan hanya menjual sesuatu barang tetapi menjual gagasan, karir, tempat, undang-undang, jasa, hiburan dan kegitan-kegiatan nirlaba seperti yayasan dan kegiatan keagamaan lainnya.

Dari kedua pengertian marketing tersebut dapat disimpulkan bahwa marketing adalah konsep bisnis yang dirancang dengan sikap mental dan cara berfikir yang harus dijiwai oleh setiap marketer dalam melaksanakan aktivitas penjulalan yang bukan hanya menjual barang tetapi juga menjual jasa, hiburan, tempat dan kegiatan-kegiatan lainnya. Seorang marketer juga harus mampu mengetahui secara luas mengenai konsep pemasaran. Seperti melakukan perubahan jika terjadi ketidaksesuaian konsep bisnis yang sebelumnya dirancang, mengetahui compotitor dan target konsumen dalam memasarkan barang, mendalamai visi dan misi perusahaan dalam mencapai tujuan yang diharapkan secara bersama-sama. Dalam marketing juga harus mampu membedakan antara strategi (segmentation, targetting, positioning), tactic (differentiation, marketing mix, selling) dan Value (brand, service, process). Tujuannya adalah agar marketer dapat melakukan aktivitas penjualan yang tepat sasaran dan tepat impliksi konsep pemasarannya.

\section{Disruption}

Disruption kembali dipopulerkan oleh Peter H Diamandis (Peter H. Diamandis, 2016, p. 7) dalam bukunya Bold: How to Go Big, Create Wealth and Impact the World; hidup saat ini berada pada dunia yang global dan eksponensial. Masalah yang muncul adalah pikiran linier manusia muncul secara harfiah tidak bisa mencapai perkembangan eksponensial. Maka perlu memiliki pemahaman yang lebih baik dan utuh untuk mengetahui perubahan-perubahan yang akan dan sedang terjadi. Maka perlu memahami ciri eksponensial. Untuk mengetahui lebih mendalam, selanjutnya Diamandis mengembangkan konsep yang disebut dengan The Six DS yang dimulai dari Digitalization, Deception, Disruption, Demonetization, Dematerialization, dan yang terakhit Democratization. Untuk lebih jelasnya akan terlihat pada kurva disrupsi pada gambar berikut ini:

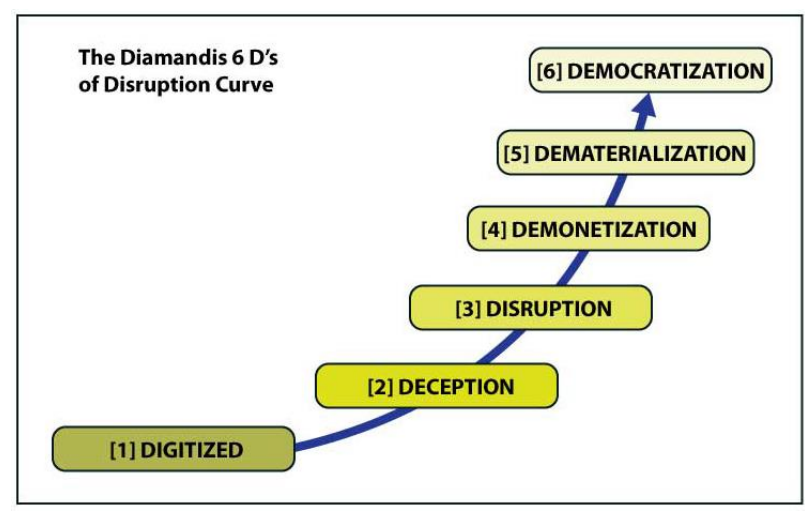

Gambar 2 The Six Ds

Sumber: Buku Bold: How to Go Big, Create Wealth and Impact the World 
Digitalization adalah transformasi dari analog ke digital. Proses yang kemudian diberdayakan secara eksponensial. Contohnya, musik dan buku yang kemudian ditransformasikan menjadi digital berbentuk MP3, MP4, PDF dan lain-lain. Deception adalah dimana kurva selanjutnya yang menggambarkan ciri eksponensial yang memiliki kecepatan perubahan dari kelipatan kecil yang kemudian akan menjadi besar. Contohnya, ketika Kodak tertipu yang memperkirakan teknologi mereka tidak bisa menggantikan keindahan dan ketajaman foto manual, karena saat itu resolusinya masih 0,1 Mega Pixel. Disruption adalah segala sesuatu yang berinovasi untuk memberikan efek dan mengganggu pasar yang sudah ada, sehingga menciptakan pasar yang baru. Contohnya, ketika kamera digital semakin menaikkan resolusinya yang sampai 2 mega pixel yang menyamai hasil kamera analog. Sehingga Kodak mulai khawatir dengan disrupsi yang terjadi. Ketika Nokia dan blackbarry terdisrupsi oleh android, akibatnya perlahan keduanya hilang dari pasar.

Demonitization adalah penghapusan uang dan menggantikannya dengan persamaan yang semua dapat dinikmati dengan mudah dan murah. Contohnya, ketika mudahnya mencari informasi di google, mudahnya bertransaksi dengan uang digital seperti Dana, Vivo, e-money dan serial Film yang sangat mudah diakses di gawai masing-masing yang sangat mudah dan murah. Dematerialization adalah lenyapnya barang dan jasa yang dibayarkan. Maksudnya adalah tidak berharganya alat perangkat yang dibeli. Karena semua aktivitas dapat dilakukan di perangkat digital yang dimiliki. Misalnya ketika ingin mengambil foto tidak perlu mengambil kamera, cukup menggunkan gawai masing-masing karena fasilitas camera sudah tersedia di Smartphone masing-masing. Ketika menyimpan foto tidak perlu lagi menyimpannya di flashdisck atau hardisck, karena dapat disimpan di google poto dan drive. Demogratization adalah yang pada akhir kurva yang sebelumnya biaya-biaya besar yang ditanggung menyusut begitu rendah sehingga dapat dinikmati semua kalangan. Contohnya, ketika awal mulanya kodak hanya dapat digunakan oleh kalangan tertentu saja, sekarang semua kalangan sudah dapat menggunakan camera dengan smartpone masing-masing. Inilah yang selanjutnya Diamandis menyebutnya dengan keberlimpahan untuk semua (Abundance for All).

\section{METODE PENELITIAN}

Metode penelitan yang digunakan dalam penelitian ini adalah metode penelitian kualitatif. Penelitian ini merupakan penelitian studi literatur yang digunakan untuk membandingkan teori disrupsi pada marketing di era Revolusi Industri 4.0. Literatur yang digunakan adalah berkaitan dengan pemikiran dan teori Hermawan Kartajaya dan Rhenald Kasali yang berbentuk buku dan jurnal yang berkaitan dengan disrupsi pada marketing.

\section{PEMBAHASAN}

\section{Biografi Hermawan Kartajaya}

Hermawan Kartajaya adalah Founder dan Chairman Markplus yang didirikan pada tahun 1990. Pada tahun 2002, Hermawan menjabat sebagai Presiden Word Marketing Association (WMA). Oleh Chartered Institute Marketing yang berkedudukan di Inggris (CIM-UK) menobatkan Hermawan sebagai 50 Gurus Who Hape Shaped The Future marketing, bersama sejumlah ikon dunia seperti Philip Kotler, Tom Peters, Theodore Levitt, 
Kenichi Ohmae. Dari sejumlah ikon dunia Marketing tersebut Hermawan dan Kenichi Ohmae adalah yang mewakili Asia.

Hermawan saat ini sedang merangkap jabatan sebagai Presiden Asia Counsil for Small Business dan sebgai Presiden International Council for Small Business Chapter Indonesia. Di bidang pemerintahan menjabat sebagi staf khusus Kementrian Koperasi dan UMKM Republik Indonesia dan juga sebagi dewan penasehat ahli Kapolri.

Hemawan juga salah satu pendiri PhilipKotlerCenter for ASEAN Marketing bersama Philip Kotler dan Hooi Den Huan. Hermawan telah menulis sejumlah artikel dan buku yang sudah terbit didalam negeri maupun di luar negeri. Bersama Kotler, Hermawan sudah sering menulis buku bersama seperti Repositioning Asia: From Bubble to Sustainable Economy, Rethinking Marketing, Sustainable Market-ing Enterprise, Think ASEAN: Rehinking Marketing towards ASEAN Community 2015. Attracting Investors: Marketing to Finding Funds for Your Business, dan Marketing 3.0: Values-Driving Marketing, hingga yang terbaru saat ini buku yang berjudul Marketing for Competitivenes dan Marketing 4.0: Bergerak dari Tradisional ke Digital yang sudah diterjemahkan keberbagai bahasa di dunia.

Hermawan adalah salah satu nonprofesor yang sering diundang sebagi pembicara dalam berbgai forum international di Asia, Eropa, sampai ke Amerika Serikat. Menghadiri berbgai executive education program di Universitas ternama di dunia salah satunya hadir di Harvard Business Schools Executive Education Program.

\section{Biografi Rhenald Kasali}

Rhenald Kasali adalah seorang akademisi dan pelaku bisnis. Dapat dikatakan Rhenal Kasali adalah seorang yang unik. Karena jarang sekali seorang akademisi juga sebagai seorang pelaku bisnis. Rhenald Kasali merupakan guru besar manajemen di Universitas Indonesia. Ia memperoleh gelar Profesornya pada tanggal 4 Juli 2009 dengan orasi ilmiah berjudul Keluar dari Krisis:Membangun Kekuatan baru Melalui Core Belief dan Tata Nilai. Rhenald kasali telah menulis berbagai artikel dan buku yang sudah terbit di dalam dan luar negeri. Dari berbagai buku yang ditulis memperoleh best seller dan salah satu yang terlaris saat ini adalah bukunya yang berjudul Disruption yang terbit pada tahun 2017.

Berikut ini buku-buku yang sudah ditulis dan terbit; Sembilan Fenomenda Bisnis (1997), Membidik Pasar Indonesia: Segmentasi, Targeting dan Positioning, Gramedia Pustaka Utama (1998), Sembari Minum Kopi Politiking di Panggung Bisnis, Gramedia Pustaka Utama, Sukses Melakukan Presentasi, Gramedia Pustaka Utama (2001), Change!, Gramedia Pustaka Utama (2009), Recode Your Change DNA, Gramedia Pustaka Utama (2007), Mutasi DNA Powerhouse, Gramedia Pustaka Utama (2008), Wirausaha Muda Mandiri, Gramedia Pustaka Utama (2010), Myelin: Mobilisasi intengibles sebagai kekuatan perubahan, Gramedia Pustaka Utama (2010). Buku ini menjadi rujukan perusahaanperusahaan besar di Indonesia, Cracking Zone, Gramedia Pustaka Utama (2011), Cracking Value, Gramedia Pustaka Utama (2012), Camera Branding, Gramedia Pustaka Utama (2013), Lets Change - Kepemimpinan, Keberanian, dan Perubahan, Penerbit Buku Kompas (2014), Self Driving, Mizan Publishing (2014), From One Dollar to Billion Dollars Company, Penerbit Buku Kompas (2014), Agility: Bukan Singa yang Mengembik, Gramedia Pustaka Utama (2015), Change Leadership, Non-finito, Mizan (2015), Reinventing, Mizan (2016), Curse To Blessing, Mizan (2016), Baper, Naora Books (2017), Disruption, Gramedia Pustaka 
ARTIKEL

Utama (2017), Strawberry Generation, Mizan (2017), Tomorrow Is Today, Mizan (2017), Self Disruption, Mizan (2018), The Great Shifting, Gramedia Pustaka Utama (2018), \#MO, Mizan (2019).Sedangkan untuk pengalaman karir sebagai praktisi bisnis, Rhenald Kasali telah menduduki berbagai posisi strategis diperusahaan ternama seperti; Komisaris Utama PT. Telekomunikasi Indonesia (Persero) Tbk (Mei 2019 - sekarang), Komisaris Utama PT. Angkasa Pura 2 (Persero) (2015 ), Ketua Komite Audit PT Indomobil Finance Indonesia Tbk, Komisaris Independen PT Indomobil Finance Indonesia Tbk (2004- Juni 2019), Komisaris Independen PT Indofarma (persero), Tbk. (2003-2006), Ketua Komite Audit PT Indofarma (persero), Tbk. (2003-2006), Komisaris PT Dirgantara Indonesia (persero) (2003-2006), Komisaris PT Radio Smart FM (2002-2009), Komisaris PT Kemenangan Jaya (2000-2007).

Rhenald Kasali memiliki pemikiran yang visioner. Konsep-konsep perubahan yang digagasnya bertujuan untuk mengadaptasi terhadap perkembangan yang terus berubah. Dalam upaya Rhenald Kasali membangun dan berkontribusi kepada kemajuan dan kesejahteraan rakyat, ia menidirikan Rumah Perubahan sebagai wadah pengabdian kepada masyarakt. Cara-cara baru ia terapkan dengan mengimplementasikan teori yang digagasnya untuk Rumah Perubahan.

\section{Disrupsi Pada Marketing Menurut Hermawan Kartajaya}

Disruption menurut Hermawan, Kotler dan Huan dalam bukunya Marketing for Competitivenes menyebutnya dengan Marketing 4.0. Era transisi dan adaptasi pada ekonomi digital serta pendekatan pemasaran baru untuk penyeimbang dari gangguan teknologi (disruptive technology). Sehingga muncul konsep pemasaran baru (Marketing 4.0) sebagai pengembangan marketing 3.0 sebelumnya yang berkonsep manusia-sentris (Kotler et al., 2017, p. 54).

Berikut ini adalah perkembangan dan perubahan marketing menurut (Kartajaya, 2019, p. 75) yang dibagi kedalam empat tahap. Marketing 1.0 adalah mengutamakan produk sebagai andalan untuk diiklankan product-driven. Akibatnya, pengetahuan tentang produk menjadi modal utama dari para penjual. Pada tahap ini, penjual tidak peduli dengan kondisi yang dialami konsumen. Penjual hanya fokus pada produk yang dipasarkan dan menyakinkan konsumen untuk membeli. Konsep pada tahap ini tidak memiliki konsep pemasaran yang istimewa. Marketing 2.0 adalah merupakan tahap pendekatan customer-centric. Pada tahap ini penjual sudah berubah dengan tidak lagi berfokus pada produk saja. Tetapi konsumen menjadi pusat perhatian utama sebelum menentukan produk yang cocok. Pemasar mulai melakukan research terhadap perilaku konsumen mulai dari keinginan dan kebutuhan yang akan dipenuhi.

Marketing 3.0 adalah customer-centric bisa saja akan sia-sia jika pemasarannya tidak dilakukan secara human spirit. Pada tahap ini, konsep pemasaran ditantang melahirkan sebuah produk yang sesuai dengan konsumen berdasarkan human spirit (semangat kemanusiaan). Maknanya adalah konsumen harus dipandang sebagai yang memiliki pikiran, hati dan semangat. Menyesuaikan digitalisasi dengan prinsip-prinsip kemanusiaan yang dimiliki konseumen. Tidak memaksakan konsep pemasaran yang membuat konsumen semakin sulit dan kebingungan. Marketing 4.0 adalah tahapan kosep marketing baru yang mengombinasikan interaksi online dengan offline antara perusahaan dengan pelanggan. 
Meski ekonomi digital saat ini sedang berkembang, bukan berarti pemasaran offline tidak berperan. Kedauanya harus saling berhubungan dan saling mengombinasi satu sama lain. Menurut Hermawan pemasaran offline justru menjadi differensiasi ditengah pasar yang competitive saat ini. Keduanya berperan dalam customer path dalam konsumen memutuskan membeli. Pada konsep marketing 4.0 konsep loyalitas konsumen telah diidentifikasi berubah dari yang sebelumnya customer path yang terakhir adalah membeli lagi (4A) bertambah menjadi (5A) dimana ada tambahan baru advocate sebagai customer path baru (Kartajaya, 2019, p. 320).

\section{Disrupsi Pada Marketing Menurut Rhenald Kasali}

Selanjutnya disruption menurut Rhenald Kasali adalah perubahan yang membuat produk, teknologi, cara dan metode dimasa lalu menjadi absolete. Perubahan ini akibat dari inovasi yang besar dan radikal (Kasali, 2018). Ada lima hal yang sangat penting menurut Rhenald Kasali tentang disrupsi dalam (Arifin, 2019, p. 6). Diantaranya adalah; proses bisnis yang simpel menghasilkan penghematan biaya, menghasilkan kualitas yang lebih baik dari produk sebelumnya, menciptakn pasar baru dari yang eksklusif menjadi inklusif, produk yang dihasilkan dapat dijangkau semua kalangan, membuat segalanya lebih mudah, smart, hemat dan lebih akurat.

Selanjutnya Rhenald Kasali dalam buku terbarunya dengan judul Mobilisasi dan Orkestrasi (\#MO), menjelaskan kembali bahwa ada lima perubahan terbaru dari seri disruption bagi kelangsungan bisnis yang dihadapi saat ini (Kasali, 2019, p. 3). Pertama, munculnya tagar-tagar yang bertujuan untuk menciptakan sesuatu yang hype. Bisa saja tujuan yang diciptakan untuk menjatuhkan atau mengembangkan sesuatu demi mengaharapkan keuntungan. Kedua, super app mulai merambah. Bisnis-bisnis lama seperti ritel, media, transportasi, keungan, kesehatan, pertanian, industri, dan pertahanan berpindah ke platform dengan dibentuk dan di-orkestrasi oleh super app. Ketiga, terjadi fenomena the main is no longer the main. Cotohnya, surat kabar tidak bisa lagi hidup hanya menjual koran dan iklannya, pelabuhan tidak mungkin lagi mengandalkan ongkos pandu dan tuda, telekomuniksi tidak lagi mengandalkan voice dan data dan seterusnya. Keempat, munculnya kesempatankesempatan baru, binis baru dan peta perasaingan baru yang sebelumnya tidak bisa diterjemahkan dengan kategori lama. Kelima, membutuhkan power untuk melakukan mobilisasi. Yakni dengan menggunakan new power dan meninggalkan old power .

\section{Implementsi Teori Hermawan Kartajaya pada Industri 4.0}

Untuk mendeskripsikan implementasi teori oleh Hermawan Kartajaya, berikut ini akan dijelaskan kedalam dua pendekatan yakni pendekatan konsep pemasaran baru dari tradisionl ke digital dan pendekatan konsep pemasaran omni channel (kombinasi saluran offline dan online) (Kotler et al., 2019).

\section{Pemasaran Baru dari Tradisional ke Digital}

Pemasaran baru dari tradisional ke digital adalah merupakan pendefenisian ulang yang dikonsep oleh Hermawan, Kotler dan Setiawan. Untuk menggambarkan implementasi pada pendekatan ini akan dijelaskan lima konsep pemasaran baru yang mengadaptasi perubahan pasar baru dari tradisional ke digital, yaitu: 
ARTIKEL

a. Dari segmentasi dan penargetan ke konfirmasi komunitas pelanggan; Segmentasi dan penargetan adalah merupakan strategi merek. Dalam ekonomi digital, pelanggan telah terhubung secar horizontal. Konsumen bukan lagi sebagai objek yang berada dibawah produsen, tetapi searah dalam menciptakn merek secara bersama-sama. Konsumen pada era digital saat ini telah menciptakan komunitasnya sendiri. Mereka melakukan percakapan terhadap merek yang mereka konsumsi. Konsumen dengan sendirinya dapat mengadvokasi dan membela merek secara loyal. Hal inilah yang membuat produsen memiliki low-budget dalam hal riset pasar. Karena produsen hanya cukup mengidentifikasi dan menjaga komunitas yang sudah terbangun.

b. Dari pemosisian merek dan diferensiasi ke klarifikasi merek; Pemosisian merek pada marketing tradisional adalah sebagai cara untuk membedakan produk dengan produk pesaing. Dalam ekonomi digital, kini difasilitasi dan diberdayakan untuk mengevaluasi bahkan meneliti janji pemosisian merek perusahaan manapun. Berkembangnya media sosial, tidak lagi bisa memberikan janji palsu dan pemosisian merek yang tidak berdasar. Karena semuanya telah terbuka dan mudah untuk mengakses informasi tentang produk yang dipasarkan. Perkembangan teknologi yang distruptive dimana siklus hidup produk semakin pendek, maka harus cukup dinamis untuk berperilaku dengan cara tertentu dalam situasi tertentu.

c. Dari menjual $4 P$ ke komersialisasi 4C; Bauran pemasaran pada marketing tradisiona adalah terdisri dari product, price, place dan promotion. Kini konsep pemasaran baru telah berkembang untuk mengakomodasi lebih banyak partisipasi pelanggan. Bauran pemasaran didefenisikan ulang menjadi $4 \mathrm{C}$ yakni:

1). Dari product ke co-creation: pelibatan pelanggan, pesaing dan unsur penunjang lainnya dalam menciptakan produk

2). Dari price ke currency: Harga pada ekonomi digital menjadi sangat fluktuatif persis seperti mata uang. Harga tidak bisa lagi sama dan tetap akan berubah sesuai dengan permintaan konsumen dan pasar.

3). Dari palce ke communal activation: Akses produk dan jasa yang tetap telah berubah menyesuaikan permintaan konsumen. Adakalanya tempat dapat berpindah dari tempat satu ke tempat lainnya. Atau sering disebut dengan virtual. Tempat bisa saja hanya dihuni oleh merek, sedangkan pekerja dapat bekerja dari tempat mana saja.

4). Dari promotion ke conversation: Promosi pada marketing tradisional selalu tertuju untuk khalayak dan biasanya hanya satu atau dua arah. Tetapi dalam ekonomi digital, promosi pemasaran akan dilakukan dari berbagai arah. Percakapan tentang produk yang dipasarkan terus berkembang dengan adanya media sosial dan media digital promosi lainnya.

5). Dari proses layanan pelanggan ke pelayanan pelanggan kolaboratif; Pada layanan tradisional pelanggan dianggap sebagai raja. Namun dalam marketing sekarang, pelanggan harus dilibatkan dalam pengembangan pelayanan Kolaborasi yang dibangun diharapkan dapat memberikan masukan dan menciptakan layanan yang masing-msing dapat diterima perusahaan dan pelanggan..

6). Kerangka Kerja Baru Pemasaran dari Jalur Pelanggan 4A ke 5A : Jalur pelanggan yang dikenal dengan sebutan AIDA atau 4A (aware-menyadari, attitute-sikap, 
act-bertindak, act again-bertindak lagi. Pada pendekatan tradisional, customer path ini masih besifat pribadi karena pengaruh utama terhadap keputusan yang dibuat pelanggan saat mereka melangkah melintasi jalurnya berasal dari titik sentuh perusahaan. Misal, iklan TV pada tahap menyadari, tenaga penjualan pada tahap bertindak, pusat layanan tahap bertindak lagi. Ini masih dalam kendali perusahaan tidak adanya konektifitas dengan pelanggan. Di era ekonomi digital saat ini kerangka kerja pemasaran jalur pelanggan kembali dimodifikasi menjadi jalur pelanggan 5A. Jalur pelanggan era konektifitas tersebut adalah Awaremenyadari, Appeal-tertarik, ask-bertanya, act-bertindak, dan Advocatemenganjurkan.

Dari uraian diatas, maka dapat disimpulkan dengan diilustrasikan pada gambar dibawah ini:

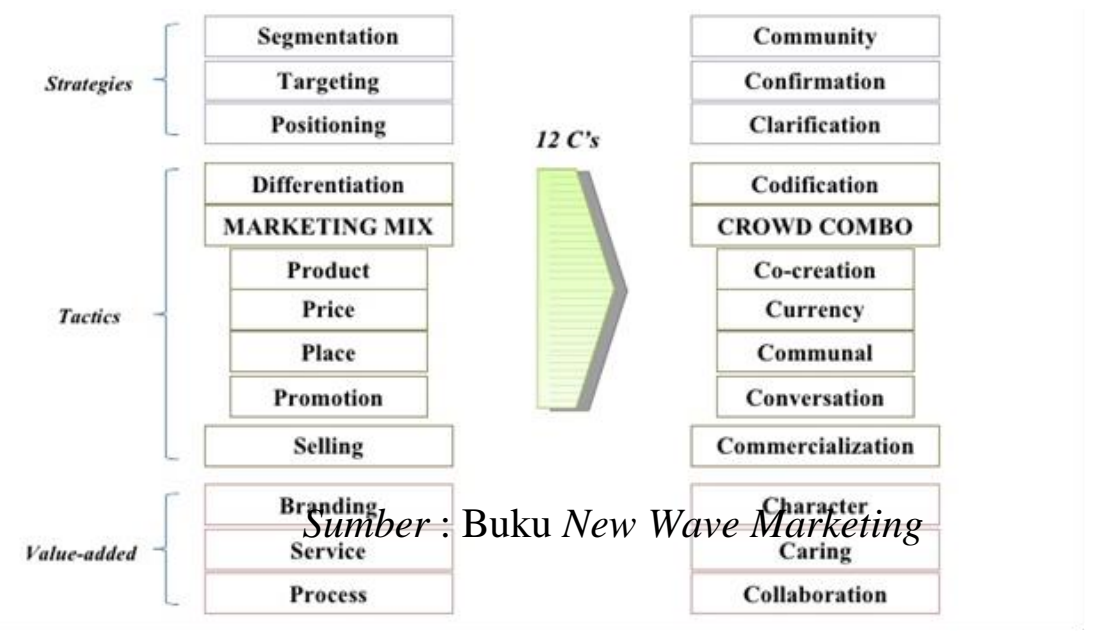

\section{Gambar 3 Kerangka Konsep Pemasaran Baru}

\section{Kombinasi saluran Offline dan Online}

Omni channel adalah suatu konsep pengalaman berbelanja yang dilakukan konsumen dengan melakukan pengalaman pengenalan produk sampai membeli dengan berbagai saluran offline dan online secara bergantian. Menurut Hermawan pemasaran omni saluran adalah praktik memadukan beberapa saluran untuk menciptkan pengalaman pelanggan yang mulus dan konsisten. Pada ekonomi digital, pemasaran omni channel ini harus diperhatikan oleh para marketer. Karena era pemasaran saat ini sangat rumit. Banyak sekali titik sentuh yang dilalui konsumen sebelum melakukan keputusan pembelian. Pergantian saluran konsumen yang awalnya memperoleh informasi suatu produk dari saluran online kemudian mencobanya dengan saluran offline yang kemudian melakukan keputusan pembelian apabila pengalaman pengetahuan tentang merek sudah diketahui.

\section{Implementsi Teori Rhenald Kasali pada Industri 4.0}

Untuk mendeskripsikan implementasi teori Rhenald Kasali dilakukan dengan menyertakan penjelasan tentang enam pilar teknologi, lima elemen penggerak jari dan bauran mobilisai online (Kasali, 2019). 


\section{ARTIKEL}

\section{Enam Pilar Teknologi}

Enam pilar teknologi adalah merupakan pendekatan baru berbasis Revolusi industri 4.0 untuk melakukan mobilisasi dan orkestrasi, yakni yang terdiri dari Internet of Things, Claud Computing, Big Data Analytics, Artificial Inteligence, Super App, dan Broadbrand Infrastructure. Dari ke enam pilar ini saling mendukung dalam memobilisasi segala kebutuhan konsumen. Sabagi contoh, super app yang merupakan aplikasi yang dapat diunduh lebih dari 3.5 miliar penduduk dunia, berperan dalam mobilisasi konsumen kearah yang diharapkan oleh pihak tertentu baik konsumen maupun produsen. Peran IoT atau Internet of Things untuk memanfaatkan device sebagai sensor dalam mengirim data. Perannya digunakan oleh Google Maps untuk memperkaya jenis data di dalam cloud. Melalui data analyticals, big data dapat memberikan detail yang kemudian diolah oleh alogaritma masingmasing platform dan super app. Dari contoh diatas dapat dilihat bahwa tidak perlu menjadi orang hebat untuk berbisnis dengan memobilisasi konsumen. Cukup menggunkan pilar-pilar teknologi yang sudah ada dan berkembang saat ini.

\section{Bauran Mobilisasi Online}

Bauran mobilisasi online bertujuan untuk membuat opini-opini publik yang menggerakkannya kearah gerakan massa yang berpengaruh hingga menjadi viral. Berikut ini bauran mobilasi online yang disingkat dengan Share :

\section{a. Story (narasi yang kuat)}

Untuk pengimplementasian teknik mobilisasi yang positif adalah dengan menerapkan story. Story adalah narasi yang kuat yang dikembangkan dan digerakkan secara online. Tujuannya adalah untuk memperdaya persepsi konsumen tentang produk yang dipasarkan. Membangun narasi yang baik akan memberikan pengaruh yang signifikan dalam upaya produsen mempromosikan produknya dipasaran. Sebaliknya jika narasi yang kurang baik, akan memerikan pengaruh yang negatif terhadap perilaku konsumen melihat produk yang dipasarkan. Tetapi pada kasus tertentu story yang kurang baik justru akan memberikan pengaruh terhadap ketenaran individu pembuat narasi tersebut. Sebagai contoh, ketika banyak sekali saat ini selebrity yang menyebarkan story yang kurang baik tentang individunya, dengan sengaja untuk memperoleh rating dan pengenalan berita tentang individu tersebut di media TV dan media sosial. Hasilnya sangat signifikan, hasilnya pada era saat ini hal-hal kurang baik sebaliknya dimobilisasi untuk mendoprak popularitas individu dan dapat diterima oleh masyarakat era industri 4.0.

\section{b. Hype (menggunakan arus yang sedang menggema)}

Memanfaatkan arus yang sedang berkembang dimasyarakat menjadikan orkestrasi tidak begitu banyak dilakukan. Misalnya pada kegitan Harbolnas. Arus ini dapat digunakan pada saat harbolnas sebelum dan atau pada saat dilakukan dengan mengadakan serangkaian giveaway dengan berbagai hadiah yang menarik. Tujuannya adalah untuk mengorkestrasi konsumen berbelanja di toko tersebut.

\section{c. Actionable (memberi ruang untuk dipertajam netizen)}

Melibatkan netizen dalam mempertajam narasi yang dikembangkan. Produsen harus mampu membangun narasi yang memberikan stimulus kepada konsumen ikut serta dalam keterlibatan pembangunan narasi untuk selanjutnya diorkestrasi oleh produsen. 


\section{d. Relevant dan Emotional (konteks dan kualitas emosi agar narasi cepat tersebar)}

Narasi yang diciptakan harus relevan dan penuh dengan sarat emosi agar konsumen dengan mudah terorkestrasi. Relevant dan emotional adalah tentang audiens. Anggaplah seorang petani bercocok tanam. Jika Hype berkaitan dengan kondisi tanah dan cuaca, maka relevant-emotional adalah kualitas benihnya. Maka dalam menyusun narasi iklan harus mampu menghadirkan story yang menyentuh dan relevant. Relevansi iklan yang ditayangkan yang penuh emosional apalagi ditampilkan dengan sarat emosional akan memudahkan penjual mengorkestrasi konsumen melakukan keputusan pembelian. Contohnya, ketika Bank Indonesia meneluarkan uang baru dengan nominal tujuh puluh lima ribu rupiah yang bertepatan dengan hari Kemerdekaan Republik Indonesia. Dengan narasi yagn penuh sarat emosi yang diorkestrasi Bank Indonesia, karena memiliki uang nominal baru tersebut adalah merupakan uang nominal yang hanya sedikit saja dicetak atau terbatas, sehingga mengorkestrasi masyarakat untuk dapat memilikinya.

\section{Lima Elemen Penggerak Jari}

Lima elemen penggerak jari dalah merupakan pendekatan baru berbasis Revolusi industri 4.0. Magnitude adalah jangkauan sauatu isu terhadap audiense. Sebagai contoh, ketika pemerintah provinsi mengumumkan tentang regulasi ojek online, maka magnitudenya hanya terbatas pada batas lingkup provinsi saja. Namun jika yang mengumumkan adalah Kementerian Perhubungan, maka magnitudenya akan sampai secara nasional. Proximinity adalah berkaitan dengan agama, budaya, gender, suku, wilayah dan seterusnya. Hal ini berkaitan dengan audiens. Drama adalah mayoritas orang suka dengan dramatis. Maka ketika promosi pemasaran yang disertakan dengan drama orang akan semakin penasaran yang akhirnya ingat dengan produk yang dipromosikan tersebut. Konflik adalah sesuatu yang negatif, namun faktanya konflik tidak sedikit orang yang menyukainya. Misalnya ketika terjadi konflik antar selebriti atau tokoh lain, justru konflik-konflik itu yang sering meuncul di media sosial maupun TV. Sehingga dengan sendirinya tokoh dan selebrity tersebut lebih dikenal masyarakat bahkan famornya meningkat. Ketokohan adalah ketokohan pada era saat ini tidak hanya dimiliki oleh pejabat dan para selebrity, tetapi ketokohan juga dimiliki oleh orang-orang yang memiliki pengikut yang banyak seperti subscribe dan follower yang banyak.

\section{Perbedaan dan Kesamaan Teori Hermawan Kartajaya dan Rhenald Kasali}

Berikut ini adalah perbedaan dan persamaan teori Hermawan Kartajaya dan Rhenald Kasali dalam memberikan konsep disrupsi pada marketing di era Revolusi 4.0:

a. Sebutan Konsep Disrupsi Marketing

Pada teori disrupsi marketing menurut Hermawan Kartajaya menyebutnya dengan konsep Marketing 4.0, sedangkan Rhenald Kasali menyebutnya dengan konsep \#MO (Mobilisasi dan Orkestrasi). Adapun persamaannya adalah memiliki kesamaan dengan memanfaatkan crowd-kerumunan untuk menerapkan pemasaran baru.

b. Dampak Perkembangan Disrupsi

Hermawan Kartajaya menjelaskan dampak perkembangan disrupsi menjadikan konsumen menjadi inklusif, sosial dan horizontal. Sehingga perlu dilakukan 
pendefenisian ulang berbagai teori pemasaran yang baru, kombinasi saluran offline dan online. Sedangkan Rhenald Kasali menjelaskan dampak perkembangan disrupsi dengan lima perubahan yakni, proses bisnis yang simpel menghasilkan penghematan biaya, menghasilkan kualitas yang lebih baik dari produk sebelumnya, menciptakan pasar baru dari yang eksklusif menjadi inklusif, produk yang dihasilkan dapat dijangkau semua kalangan, membuat segalanya lebih mudah, smart, hemat dan lebih akurat. Maka menurut Rhenald Kasali, perlu dilakukan pendekatan baru dan pemasaran baru. Adapun persamaannya adalah sama-sama berpendapat bahwa konsumen era sekarang sudah sangat terbuka dan cenderung inklusif.

c. Konsep Marketing Baru

Hermawan Kartajaya melakukan pendefenisian ulang terhadap teori konsep marketing tradisional ke digital. Seperti segmentasi menjadi community, targetting menjadi confirmation, positioning menjadi clarification, differentiation menjadi codification, marketing mix menjadi crowd-combo, selling menjadi commercialization, promotion menjadi conversation dan perubahan customer path dari 4A menjadi 5A (Aware, Appeal, Ask, Act dan Advocate). Sedangkan Rhenald Kasali menambahkan konsep baru dengan sebutan Mobilisasi dan Orkestrasi dengan konsep intinya adalah memanfaatkna enam pilar teknologi, menggerakkan konseumen dengan lima elemen penggerak jari dan bauran mobilisasi online. Adapun kesamaannya adalah keduanya sama-sama berfokus pada pemanfaatan konsep jalur pelanggan dari bagaimana konsumen yang sebelumnya belum sadar tentang merek, kemudian mengupayakan konsumen tersebut sadar dan selanjutnya melakukan proses pemelian dan penganjurann ke konseumen lain.

\section{E. KESIMPULAN}

Dari kedua pendapat diatas, memiliki kesamaan bahwa terjadinya disrupsi terhadap pemasaran dan teknologi menjadikan produsen mencari solusi untuk memenuhi segala kebutuhan dan keinginan konsumen di era yang dinamis saat ini. Kesamaan yang terlihat adalah pada pendapat bahwa disrupsi terjadi akibat dari inovasi yang terjadi terhadap caracara baru yang diimplementasikan produsen terhadap konsumen. Cara-cara baru yang dilakukan produsen tersebut akibat dari perilaku konsumen yang semakin smart dan semakin terbuka karena adanya perkembangan teknologi. Maka dapat disimpulkan bahwa disruption adalah segala sesuatu yang berubah akibat dari gangguan dan inovasi yang berkembang, yang menghasilkan dorongan terhadap upaya menciptakan pasar baru, metode baru, dan teknologi yang baru untuk menggantikan pasar lama, metode lama dan teknologi yang lama.

Perkembangan teknologi yang selalu memberikan gangguan terhadap pasar dan metode yang sudah ada. Seorang marketer harus mampu menerapkan teori-teori baru yang sudah dikonsep Hermawan Kartajaya dan Rhenald Kasali. Hal ini harus dilakukan karena pasar sekarang sudah berubah mengikuti perkembangan dan disruptive teknologi. Kedua pakar tersebut adalah merupakan representative dari berbagai pakar-pakar pemasaran yang sedang mengembangkan konsep pemasaran baru. Kredibilitas keilmuan yang mereka miliki sudah dapat diuji ditingkat nasional dan internasional.

Perbandingan teori Hermawan Kartajaya dan Rhenal Kasali, keduanya saling memberikan kesamaan sekalipun beberapa teori secara penyebutan tidak memiliki kesamaan. 
ARTIKEL

Namun teori keduanya sama-sama berfokus pada jalur dan loyalitas pelanggan yang membahas tentang bagaimana konsumen dapat melakukan proses keputusan pembelian yang pada Hermawan Kartajaya menyebutnya dengan customer path 5A sedangkan pada Rhenald Kasali menyebutnya dengan Online Mobilization Mix: Share.

\section{DAFTAR PUSTAKA}

Arifin, S. (2019). Pemasaran Era Milenium. CV. Budi Utama.

Dalenogare, L. S., Benitez, G. B., Ayala, N. F., \& Frank, A. G. (2018). The expected contribution of Industry 4.0 technologies for industrial performance. International Journal of Production Economics, 204(July), 383-394.

Darwin, M. (2020). The Effect of Communication Strategy in Marketing 4.0 Purchase Decision through Brand Advocacy in Shopee E-Commerce. Jurnal Ilmiah MEA (Manajemen, Ekonomi, \& Akuntansi), 4(2), 375-396.

Kartajaya, H. (2002). Hermawan Kartajaya on Marketing. Jakarta: Gramedia Pustaka Utama.

Kartajaya, H. (2019). Citizen 4.0: Menjejakkan Prinsip-Prinsip Pemasaran Humanis Di Era Digital. Jakarta: Gramedia Pustaka Utama.

Kasali, R. (1998). Membidik pasar Indonesia: segmentasi, targeting, dan positioning Jakarta: Gramedia Pustaka Utama.

Kasali, R. (2018). Self Disruption. Bandung: Mizan.

Kasali, R. (2019). \#MO: Sebuah Dunia Baru yang Membuat Orang Gagal Paham. Jakarta: Gramedia Pustaka Utama.

Kotler, P., Kartajaya, H., \& Huan, H. Den. (2017). Marketing for Competitiveness. Jakarta: PT. Bentang Pustaka.

Kotler, P., Kartajaya, H., \& Setiawan, I. (2019). Marketing 4.0 : Bergerak dari Tradisional ke Digital. Jakarta: Gramedia Pustaka Utama.

Peter H. Diamandis, S. K. (2016). Bold: How to Go Big, Create Wealth and Impact the World. Simon \& Scuster Paperbacks.

Potsangbam, C. (2018). Adaptive Performance in VUCA Era-Where is Research Going? International Journal of Management (IJM), 8(6), 99-108. 